\title{
ADAMTS-7 promotes vascular smooth muscle cells proliferation in vitro and in vivo
}

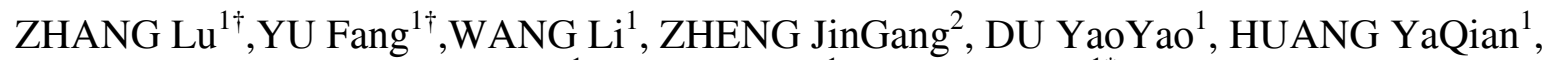 \\ LIU Bo ${ }^{1}$, WANG Xian ${ }^{1} \&$ KONG Wei ${ }^{1 *}$ \\ ${ }^{1}$ Department of Physiology and Pathophysiology, School of Basic Medical Sciences, Peking University; Key Laboratory of Molecular \\ Cardiovascular Science, Ministry of Education, Beijing 100191, China; \\ ${ }^{2}$ Department of Cardiology, China-Japan Friendship Hospital, Beijing 100029, China
}

Received November 7, 2014; accepted February 11, 2015; published online April 15, 2015

\begin{abstract}
Vascular smooth muscle cell (VSMC) proliferation and migration are pivotal for the pathogenesis of atherosclerosis and post-angioplasty restenosis. We have recently reported that a disintegrin and metalloproteinase with thrombospondin motifs-7 (ADAMTS-7), a novel metalloproteinase, contributes directly to neointima formation by mediating VSMC migration. However, whether ADAMTS-7 affects VSMC proliferation remains unclear. In this study, we found that luminal adenoviral delivery of ADAMTS-7 aggravated intimal hyperplasia $7 \mathrm{~d}$ after injury, paralleled by an increased percentage of PCNA-positive cells in both intima and media. In contrast, perivascular administration of ADAMTS-7 siRNA, but not scrambled siRNA to injured arteries attenuated intimal thickening at day 7, paralleled with reduced intimal VSMC replication, without alteration of VSMC proliferation in the media. In accordance, $\left[{ }^{3} \mathrm{H}\right]$-thymidine incorporation assay in primary cultured rat VSMCs revealed an enhanced replication rate (by 61\%) upon ADAMTS-7 overexpression and retarded proliferation (by 23\%) upon ADAMTS-7 siRNA administration. Our data demonstrates that ADAMTS-7 promotes VSMC proliferation both in vitro and in vivo. ADAMTS-7 may therefore serve as a novel therapeutic target for atherosclerosis and post-angioplasty restenosis.
\end{abstract}

vascular smooth muscle cell, ADAMTS-7, proliferation

Citation: Zhang L, Yu F, Wang L, Zheng JG, Du YY, Huang YQ, Liu B, Wang X, Kong W. ADAMTS-7 promotes vascular smooth muscle cells proliferation in vitro and in vivo. Sci China Life Sci, 2015, 58: 674-681, doi: 10.1007/s11427-015-4843-2

Abnormal vascular smooth muscle cell (VSMC) proliferation has been recognized as a predominant mechanism accounting for atherosclerosis and restenosis after angioplasty $[1,2]$. In healthy mature blood vessels, VSMCs exhibit a contractile phenotype, surrounded by and embedded in an extracellular matrix (ECM) scaffold, and exhibit extremely low rates of proliferation. Upon environmental stimulation such as injury, growth factors or chemokines, VSMCs in the media are converted to a synthetic phenotype and then migrate to the intima where they undergo proliferation $[3,4]$.

$\uparrow$ Contributed equally to this work

*Corresponding author (email: kongw@bjmu.edu.cn)
As a part of this process, the extracellular matrix proteins that normally surround the cells in the media and the interstitial matrix must be reorganized. Accordingly, matrix-degrading proteases have been proposed to function in modulating VSMCs migration and proliferation [5,6]. Previous studies have emphasized potential roles for the matrix metalloproteinases (MMPs) MMP-2, MMP-9 and MT1MMP, the serine proteinases, plasminogen activator and plasminogen, the cysteine proteinases, cathepsins $\mathrm{K}, \mathrm{L}, \mathrm{S}$, etc. during matrix remodeling and VSMC migration [7]. Others have demonstrated that MMPs also affect VSMC proliferation via growth factors mobilization or $\mathrm{N}$-cadherin shedding and subsequent $\beta$-catenin signaling [8]. However, 
the identification of the key proteinases during pathological vascular remodeling in vivo has remained the subject of speculation.

Recently, using a balloon-injured rat carotid artery model, we have identified the importance of a disintegrin and metalloproteinase with thrombospondin motifs-7 (ADAMTS-7), a novel ADAMTS family proteinase, in mediation of VSMC migration and promoting neointima formation following artery injury through degradation of cartilage oligomeric matrix protein (COMP) [9-11]. Moreover, ADAMTS-7 promotes VSMC and aortic calcification by disturbing the balance between osteogenic BMP-2 and its natural inhibitor COMP $[12,13]$. Three recent genome-wide association studies (GWASs) have revealed ADAMTS7 as a novel locus associated with human coronary atherosclerosis [14-16]. Further study uncovers a non-synonymous single nucleotide polymorphism (SNP) in the prodomain of ADAMTS-7 that is inversely related to VSMC migration, COMP cleavage and the prevalence of atherosclerosis [17]. However, whether ADAMTS-7 increases neointima formation by promoting VSMC proliferation remains unknown. In the current study, we demonstrated for the first time that ADAMTS-7 facilitates VSMC proliferation both in vitro and in vivo.

\section{Materials and methods}

\subsection{Animal artery injury}

All studies followed the guidelines of the Animal Care and Use Committee of Peking University. Male SpragueDawley rats (210-230 g) were used in all experiments for the carotid artery ballon-injury model. Briefly, a balloon catheter of 1.5-mm diameter (Medtronic, Minneapolis, MN, USA) was introduced through the left external carotid artery and advanced about $4 \mathrm{~cm}$ toward the thoracic aorta. The balloon was distended with gas and then pulled back to the bifurcation with constant rotation. This procedure was repeated three times to ensure complete endothelial denudation. Contralateral carotid arteries underwent a similar operation without injury and served as sham controls.

\subsection{VSMC isolation and culture}

VSMCs were isolated from the thoracic aortic arteries of 150-180 g male Sprague-Dawley rats by collagenase digestion as described previously [10]. Cells from passages 4 to 8 were used in all experiments.

\subsection{Recombinant adenovirus construction}

The adenovirus expressing ADAMTS-7 (Ad-ADAMTS-7) was constructed and amplified according to the manufacturer's protocol (BD Biosciences Clontech, CA, USA). An adenovirus expressing green fluorescence protein (Ad-GFP) was served as a negative control. For in vivo infection, immediately after balloon injury, a single exposure of $5 \times 10^{8}$ plaque forming units (pfu) of Ad-ADMSTS-7 was luminal delivered to injured carotid segments and remained for 30 min for sufficient infection. Then, the adenovirus solution was removed and blood flow was restored.

\subsection{ADAMTS-7 siRNA transfection}

ADAMTS-7 siRNA (siRNA ADAMTS-7 ) was designed using the Block-iT RNAi Designer and chemically modified by the manufacturer (Stealth siRNAs, Invitrogen, USA). Sequences corresponding to the siRNA $A_{\text {ADAMTS-7 }}$ were: sense, 5-CACA- UCACCGUUGUGCGCCUUAUUA-3; and antisense, 5-UAAUAAGGCGCACAACGGUGAUGUG-3. A scrambled Stealth RNAi duplex (catalog No. 12935, Invitrogen) was served as a negative control. For in vivo studies, $15 \mu \mathrm{g}$ of siRNA dissolved in $30 \%$ pluronic gel solution was perivascular delivered to the rat carotid arteries immediately after balloon-injury. For in vitro studies, transfection of rat primary VSMCs with the siRNA $\left(50 \mathrm{nmol} \mathrm{L}^{-1}\right)$ was performed using Oligofectamine (Invitrogen).

\subsection{Western blot analysis}

Rat artery extracts or VSMCs lysates containing equal amounts of total protein $(60 \mu \mathrm{g})$ were resolved by $10 \%$ SDS-PAGE. The membranes were incubated with primary antibody followed by IRDye 700DX-conjugated secondary antibody (Rockland Inc, Gilbertsville, PA, USA). The immunofluorescence signal was detected by the Odyssey infrared imaging system (LICOR Biosciences, Lincoln, Neb, USA).

\subsection{Analysis of morphology and cell proliferation in rat carotid arteries}

Rats were sacrificed and perfused with a $4 \%$ paraformaldehyde solution in PBS. The carotid arteries were immediately divided into two sections from the middle portion of the balloon-injured segment. Briefly, cryosections ( $7 \mu \mathrm{m}$ thickness, $350 \mu \mathrm{m}$ apart) were taken, and eight slices of each sample were analyzed by hematoxylin \& eosin staining and Spot Image software (Diagnostic Instruments, Australia). To measure cell replication in vivo, frozen sections were incubated with anti-PCNA antibodies (1:50, Santa Cruz, CA, USA), horseradish peroxidase-conjugated goat anti-rabbit IgG and 3, 3-diaminobenzidine successively. Sections were then counterstained with hematoxylin.

\subsection{VSMC proliferation assay}

For $\left[{ }^{3} \mathrm{H}\right]$-thymidine incorporation assay, DNA synthesis in VSMCs with and without appropriate treatments was measured by pulse-labeling cells for the last $6 \mathrm{~h}$ of the $48 \mathrm{~h}$ 
treatment period with $1 \mu \mathrm{Ci} \mathrm{mL}{ }^{-1}\left[{ }^{3} \mathrm{H}\right]$-thymidine. The reaction was terminated by three washes of ice-cold PBS and the radioactivity was assessed by scintillation counter (Beckman, USA). For protein determination, cells were washed gently with PBS, and protein contents were measured using a BCA protein assay kit (Pierce, Rockford, IL, USA). For the cell counting assay, VSMCs were trypsinized to single-cell suspension, and 3,000 cells were transferred to each well of a 96-well plate. Cell Counting Kit-8 (CCK-8) reagent was added $48 \mathrm{~h}$ after treatment and incubated at $37^{\circ} \mathrm{C}$ for $2-4 \mathrm{~h}$ according to the color change. The $A$ (optical density) value at $450 \mathrm{~nm}$ was read by a microplate reader (Varioskan Flash, Thermo Fisher, USA).

\subsection{Statistical analysis}

All continuous data are presented as mean \pm standard error of the mean (SEM). Protein band density was normalized to the corresponding loading control and then to the mean of the corresponding control group. Paired $t$-test (two sided) was applied to analyze the effect of ADAMTS-7 overexpression or knockdown on proliferation in VSMCs. Unpaired $t$-test (two sided) was performed in comparing PCNA positive cells in injured arteries among groups. One way ANOVA was applied to examine the effect of siRNA ${ }_{\text {ADAMTS-7 }}$ on ADAMTS-7 silencing in injured arteries, followed by Student-Newman-Keuls test for post hoc comparison as appropriate. All statistical analysis was performed by GraphPad Prism5.0 (GraphPad Software Inc, San Diego, CA, USA). A $P<0.05$ was considered statistically significant.

\section{Results}

\subsection{ADAMTS-7 overexpression promotes neointima} formation and VSMC proliferation in injured arteries

To investigate the effect of ADAMTS-7 on VSMC proliferation in vivo, we first applied adenovirus to overexpress ADAMTS-7 (Ad-ADAMTS-7) in rat balloon-injured carotid arteries. As shown in Figure 1A, successful infection was evidenced by Western blot analysis $4 \mathrm{~d}$ after injury. While ADAMTS-7 was overexpressed, neointima size was markedly increased compared with Ad-GFP infected groups $7 \mathrm{~d}$ after balloon injury (Figure 1B). In accordance, immunohistochemical staining against proliferating cell nuclear antigen (PCNA) revealed enhanced proliferation of VSMCs in both intima and media of injured arteries $7 \mathrm{~d}$ after injury (Figure 1C). The PCNA-positive cells of intima were 2-fold greater in Ad-ADAMTS-7 infected than in Ad-GFP infected vessels (ADAMTS-7 vs. GFP: $47.5 \% \pm 1.6 \%$ vs. $23.4 \% \pm$ $0.9 \%$ ) and 1.4-fold higher in media (ADAMTS-7 vs. GFP: $10.9 \% \pm 0.8 \%$ vs. $7.7 \% \pm 1.0 \%$ ), respectively (Figure 1D and $\mathrm{E})$.


C Ad-GFP
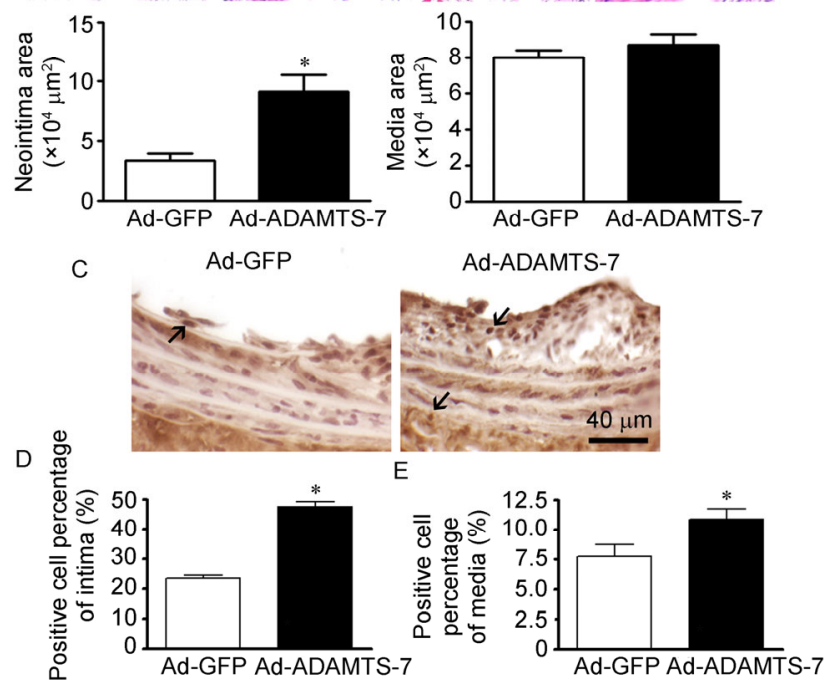

Figure 1 (color online) ADAMTS-7 promoted VSMCs proliferation in vivo. A, Representative Western blot of carotid arteries infected with ADAMTS-7 or GFP adenovirus $4 \mathrm{~d}$ post-injury. B, Photomicrographs of hematoxylin/eosin- stained rat balloon injured carotid arteries infected with Ad-GFP and Ad- ADAMTS-7. $b$ and $d$ are high magnification images $(\times 400)$ of the boxed areas in a and $c(\times 100)$, respectively. Values are mean \pm SEM. $n=6$ per group. $*, P<0.05$. C, Immunohistochemical staining of vessels with a specific anti-PCNA antibody. Arrows indicate PCNA positive cells. Quantitative analysis of PCNA positive cells in intima (D) and media (E) from histological sections of Ad-ADAMTS-7 or Ad-GFP infected arteries $7 \mathrm{~d}$ after injury. Values are mean \pm SEM. $n=6$ per group. *, $P<0.05$ vs. Ad-GFP.

\subsection{ADAMTS-7 knockdown reduces neointimal thick- ening and VSMCs replication in response to artery in- jury}

Next we asked whether ADAMTS-7 knockdown reciprocally could suppress VSMCs replication in vivo. Successful ADAMTS-7 silencing was achieved through perivascular application of specific siRNA mixed with pluronic gel (Figure 2A). In extraction from 7-day post-injured arteries, siRNA ${ }_{\text {ADAMTS-7 }}$ reduced carotid artery expression of ADAMTS-7 protein to levels comparable to those of un-injured rats (Figure 2A, $n=4-6, P<0.05$ ). Consistent with this observation, there was a robust decrease of neointima area in siRNA $A_{\text {ADAMTS-7 }}$ treated rats compared to siRNA scramble administration (Figure 2B). Consistently, PCNA positive cells in the intima of arteries with siRNA ADAMTS-7 $_{\text {knock- }}$ down were significantly less than that of siRNA $A_{\text {scramble }}$ 

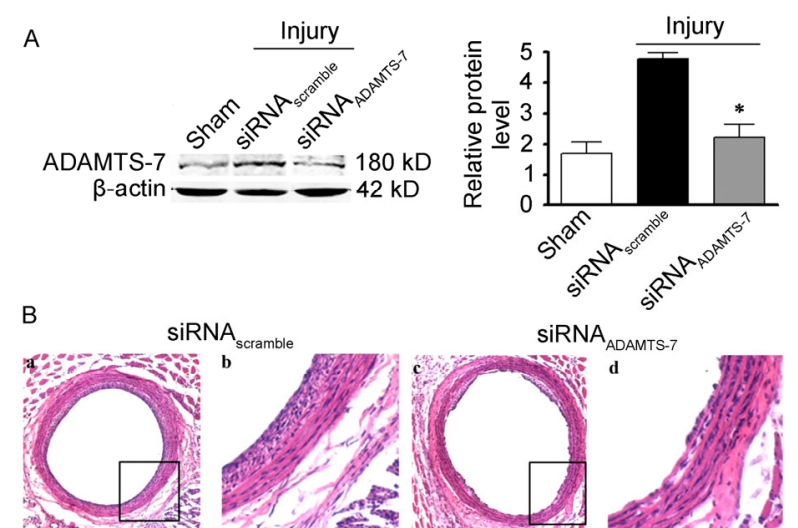

SIRNA ${ }_{\text {ADAMTS-7 }}$
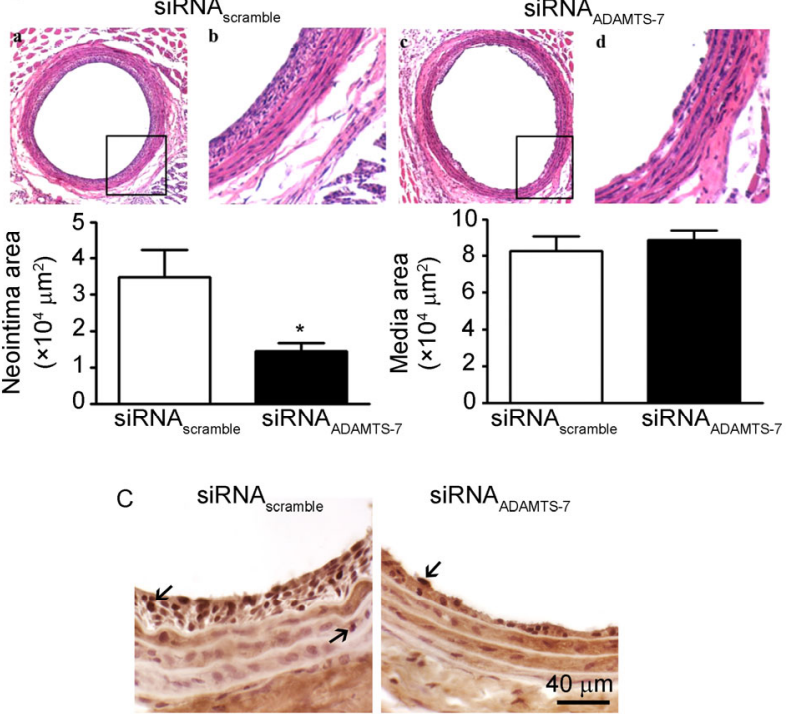

$\mathrm{D}$
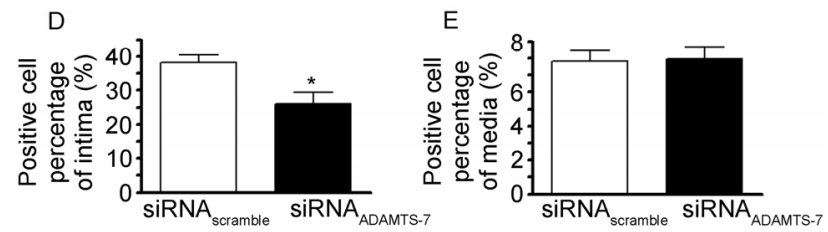

Figure 2 (color online) ADAMTS-7 knockdown by siRNA inhibited VSMCs proliferation in vivo. A, Representative Western blot (left) and quantitative analysis of ADAMTS-7 protein from sham-operated or injured rat carotid arteries treated with siRNA scramble $_{\text {or siRNA }}$ ADAMTs-7 $(n=4-6$, $* P<0.05)$. B, Representative cross sections of hematoxylin/eosin-stained carotid arteries treated by siRNA scramble $_{\text {or siRNA }}$ ADAMTS-7 $7 \mathrm{~d}$ after injury, $\mathrm{b}$ and $d$ are high magnification images $(\times 400)$ of the boxed areas from a and c $(\times 100)$, respectively. Values are mean \pm SEM. $n=6$ per group. ${ }^{*}, P<0.05$. $\mathrm{C}$, PCNA positive cells were examined by immunohistochemistry in rat carotid arteries treated with siRNA scramble $_{\text {or siRNA }}$ ADAMTS- $7 \mathrm{~d}$ after injury. Scale bar, $40 \mu \mathrm{m}$. Quantitative analysis of PCNA positive cells in intima (D) and media (E) from histological sections of arteries $7 \mathrm{~d}$ after injury. Values are mean \pm SEM. $n=6$ per group. ${ }^{*}, P<0.05$ vs. siRNA scramble

knockdown $(26.1 \% \pm 3.3 \%$ vs. $38.1 \% \pm 2.4 \%)$ (Figure $2 \mathrm{C}$ and D). In contrast, there was no difference of PCNA positive cells in the media between the two groups $(8.0 \% \pm 0.7 \%$ vs. $7.8 \% \pm 0.6 \%$ ) (Figure 2E).

\subsection{ADAMTS-7 enhances proliferation of VSMCs in vitro}

To exclude the possibility that the effect of ADAMTS-7 on VSMC proliferation in injured arteries are secondary to promotion of migration by ADAMTS-7, we further examined the effect of ADAMTS-7 on VSMC proliferation in primary isolated VSMCs. As shown in Figure 3A, infection of VSMCs with Ad-ADAMTS-7 at 10 multiplicities of infection (MOI) markedly increased ADAMTS-7 protein level compared to Ad-GFP-infected VSMCs. Therefore, we used 10 MOI of adenovirus in subsequent studies. $\left[{ }^{3} \mathrm{H}\right]$-thymidine incorporation assay revealed enhanced proliferation (by 61\%) of Ad-ADAMTS-7-infected VSMCs compared to Ad-GFP-infected cells (Figure 3B). Moreover, protein quantification assay was performed to monitor the VSMCs replication rate. As shown in Figure 3C, total protein concentration was 1.5-fold increase in Ad-ADAMTS-7 infected cells compared with Ad-GFP infected cells $3 \mathrm{~d}$ after infection. Consistently, an increase in proliferation was observed in VSMCs overexpressing ADAMTS-7 compared to the control, according to CCK-8 analysis (Figure 3D). Taken together, these data reinforce our hypothesis that ADAMTS-7 overexpression promotes VSMC proliferation.

\subsection{ADSMTS-7 silencing by siRNA ameliorates VSMCs proliferation}

Motivated by the observation that enforced expression of ADAMTS-7 facilitates VSMC proliferation in vitro, we suspected that endogenous ADAMTS-7 played a key role in VSMC proliferation. To test our hypothesis, specific siRNA was applied to silence ADAMTS-7. Knockdown of ADAMTS-7 in VSMCs was verified by Western blot analysis (Figure 4A). In agreement with in vivo study, data from $\left[{ }^{3} \mathrm{H}\right]$-thymidine incorporation assay showed that ADAMTS7 knockdown retarded VSMCs proliferation by $23 \%$ com-

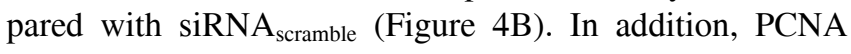
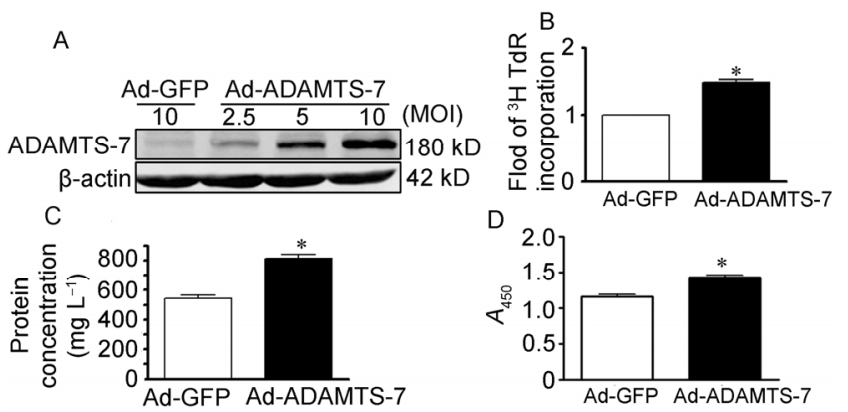

Figure 3 ADAMTS-7 enhanced proliferation of VSMCs in vitro. A, Representative Western blot of Ad-ADAMTS-7 infection in primary cultured VSMCs. $\beta$-actin was used as internal control. B, $\left[{ }^{3} \mathrm{H}\right]$-thymidine incorporation assay of VSMCs. VSMCs were treated with adenovirus followed by serum-starving for $24 \mathrm{~h}$, and subjected to PDGF-BB (25 ng $\left.\mathrm{mL}^{-1}\right)$ treatment for $48 \mathrm{~h}$ with the addition of $\left[{ }^{3} \mathrm{H}\right]$-thymidine $\left(1 \mu \mathrm{Ci} \mathrm{mL}{ }^{-1}\right)$. Results are expressed as mean \pm SEM CPM from three independent experiments performed in duplicate; $*, P<0.05$ vs. Ad-GFP. C, Cell protein assay. VSMCs were treated with adenovirus followed by serum-starving for $24 \mathrm{~h}$, and subjected to PDGF-BB (25 $\mathrm{ng} \mathrm{mL} \mathrm{mL}^{-1}$ ) for $3 \mathrm{~d}$, then whole cell lysates were harvested and the concentration was tested by BCA protein assay kit. Results are mean \pm SEM from three independent experiments performed in duplicate; *, $P<0.05$ vs. Ad-GFP. D, Proliferation of VSMCs infected with Ad-ADAMTS-7 or Ad-GFP was determined by Cell Counting Kit-8 (CCK-8). Results are mean \pm SEM from three independent experiments performed in duplicate; *, $P<0.05$. 

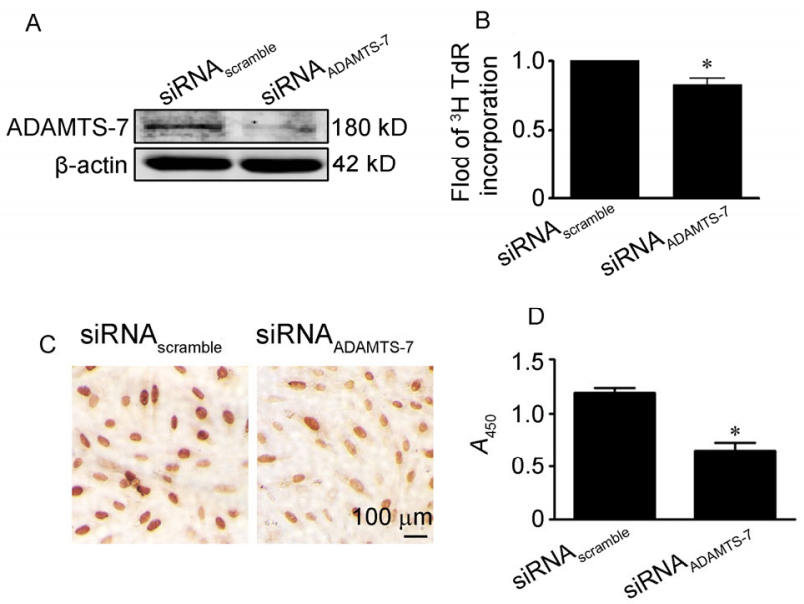

Figure 4 (color online) ADSMTS-7 knockdown by siRNA ameliorated VSMCs proliferation in vitro. A, Representative Western blot of ADAMTS-7 protein level in VSMCs $48 \mathrm{~h}$ after transfection with siRNA $_{\text {scramble }}$ or siRNA ADAMTS-7. $_{\text {B }}$, VSMCs were transfected with either siRNA $_{\text {scramble }}$ or siRNA ADAMTS-7 $_{\text {for }} 48 \mathrm{~h}$, subsequently followed by addition of $\left[{ }^{3} \mathrm{H}\right]$-thymidine $\left(1 \mu \mathrm{Ci} \mathrm{mL}{ }^{-1}\right)$. The radioactivity was assessed by scintillation counter. Results are expressed as mean \pm SEM CPM from three independent experiments performed in duplicate; ${ }^{*}, P<0.05$ vs. siRNA scramble. $_{\text {. }}$, Representative immunohistochemical staining against PCNA was performed in VSMCs $48 \mathrm{~h}$ after siRNA scramble $_{\text {or siRNA }}$ ADAMTS-7 transfection. Scale bar, $100 \mu \mathrm{m}$. D, Proliferation of VSMCs transfected with siRNA scramble $_{\text {. }}$

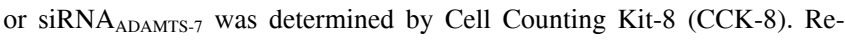
sults are mean \pm SEM from three independent experiments performed in duplicate; ${ }^{*}, P<0.05$.

positive cells revealed by PCNA staining in primary VSMCs was also decreased in ADAMTS-7 knockdown groups compared to scrambled groups (Figure 4C). CCK-8 assay revealed a reduced proliferation in siRNA ADAMTS-7 $^{-}$ treated VSMCs compared with siRNA scramble-treated ones (Figure 4D). Taking together, our data indicates an effect of endogenous ADAMTS-7 on VSMCs proliferation in vitro.

\subsection{COMP has no effect on VSMC proliferation}

Our previous studies have shown that ADAMTS-7 directly binds to and degrades COMP in VSMCs and injured vessels and subsequently promotes VSMC migration $[9,10]$. Since COMP is the solely identified substrate of ADAMTS-7, we then examined whether COMP also affected VSMC proliferation. Interestingly, COMP overexpression had no effect on VSMC proliferation in $\left[{ }^{3} \mathrm{H}\right]$-thymidine incorporation assay (Figure 5A). Furthermore, silence of endogenous COMP in VSMCs did not affect cell proliferation in CCK-8 assay (Figure 5B). Moreover, overexpression of COMP exhibited no effect on the aggravated proliferation by excessive ADAMTS-7 (Figure 5C). Thus, other substrate of ADAMTS-7 but not COMP may mediate its effect on VSMCs migration.

\section{Discussion}

We have recently demonstrated that ADAMTS-7 plays a
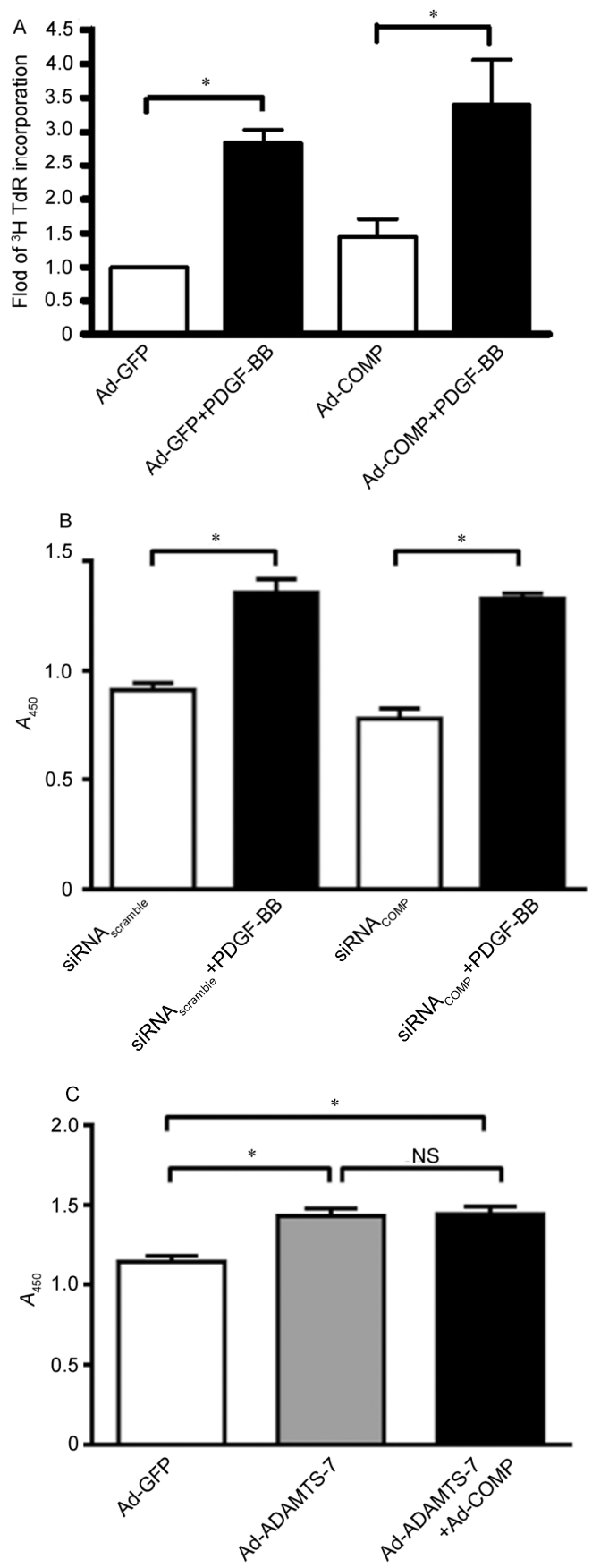

Figure 5 COMP had no effect on VSMCs proliferation. A, VSMCs were treated with adenovirus followed by serum-starving for $24 \mathrm{~h}$, and subjected to PDGF-BB (25 $\mathrm{ng} \mathrm{mL} \mathrm{m}^{-1}$ ) or culture alone for $48 \mathrm{~h}$ with the addition of $\left[{ }^{3} \mathrm{H}\right]$-thymidine $\left(1 \mu \mathrm{Ci} \mathrm{mL} L^{-1}\right)$. The reaction was terminated by three washes of ice-cold PBS and the radioactivity was assessed by scintillation counter. Results are expressed as mean \pm SEM fold of Ad-GFP from three independent experiments performed in duplicate; $*, P<0.05$. B, Proliferation of VSMCs transfected with siRNA scramble $_{\text {or }}$ siRNA COMP $_{\text {was determined by }}$ CCK-8. VSMCs were treated with siRNA followed by serum-starving, and subjected to PDGF-BB (25 ng mL $\mathrm{mL}^{-1}$ ) or culture alone for another $48 \mathrm{~h}$. Results are mean \pm SEM from three independent experiments performed in duplicate; *, $P<0.05$. C, Recruitment of COMP did not effect ADAMTS-7facilitated VSMC proliferation. VSMC were co-infected with both AdADAMTS-7 and Ad-COMP and analyzed by CCK-8. Results are mean \pm SEM from three independent experiments performed in duplicate; *, $P<0.05$. NS, not significant. 
pivotal role in neointima formation in response to injury by promoting VSMC migration in vitro and in vivo [10]. In the current study, we further advanced our knowledge by demonstrating that ADAMTS-7 facilitates VSMC proliferation and subsequent intima hyperplasia. ADAMTS-7 may therefore act as a promising target for prevention and treatment of vascular proliferative diseases including atherosclerosis, post-angioplasty restenosis, vein graft disease and transplant vasculopathy.

Unlike other metalloproteinases, ADAMTS members exhibit narrow substrate specificity due to the existence of various C-terminal thrombospondin motif, which makes them potentially safe pharmaceutical targets [18]. The ADAMTS family has been implicated in various diseases such as cancer, arthritis and atherosclerosis. For example, ADAMTS-1 has anti-angiogenic activities [19] and is crucial for tumor progression [20]. ADAMTS-4 and ADAMTS-5 are important mediators of arthritis [21-23]. ADAMTS-13 is a von Willebrand factor-cleaving protease, and its mutations lead to inherited life-threatening thrombocytopenic purpura [24]. Recently, the role of ADAMTS proteases in inflammation and atherosclerosis has come to light [25]. Jonsson-Rylander and colleagues [26] reported that ADAMTS-1 might expedite atherogenesis by cleaving the ECM protein versican. The $227^{\text {Pro }}$ polymorphism in ADAMTS-1 was associated with a nearly twofold increased risk of coronary heart disease event [27]. ADAMTS-4 and -8 were also identified as inflammatory-regulated enzymes in macrophage-rich areas of human atherosclerotic plaques [28]. ADAMTS-5 can reduce the LDL binding ability of biglycan and released LDL from human aortic lesions, indicating its important role in regulating proteoglycan turnover and lipoprotein retention in atherosclerosis [29]. However, the relevance of ADAMTS family members to cardiovascular disease remains largely unknown. The ADAMTS7 locus was recently identified to have a strong association with coronary atherosclerotic disease $[15,16]$. We are the first to reveal the relevance of ADAMTS-7 on neointima formation via affecting both VSMCs migration [10] and proliferation. However, the underlying mechanism is not yet understood. The importance of ADAMTS-7 in cardiovascular disease needs to be further explored.

Excessive proliferation of VSMCs in response to injury has been related to activation of a variety of growth factors and cytokine such as basic fibroblast growth factor (bFGF) [30], platelet-derived growth factor (PDGF) [31], transforming growth factor- $\beta$ (TGF- $\beta$ ) [32], angiotensin II [33], and/or insulin like growth factor-1 (IGF) [34]. Growth factors and cytokines share a final proliferative signaling pathway, namely the cell cycle [35]. Cell cycle progression involves subtle tune of cyclins/cyclin dependent kinases (CDKs) and cyclin dependent kinase inhibitors (CKIs) such as $\mathrm{p} 27^{\mathrm{KIP} 1}$ and $\mathrm{p} 21^{\mathrm{CIP} 1}$ [36,37]. Instead of directly interfering with cell cycle proteins, MMPs have been implicated in VSMC proliferation via indirect effects, such as releasing of matrix-anchored growth factors or ablation of cell-cell contact protein like N-cadherin [8]. Nevertheless, the effect of MMPs on VSMC proliferation in vivo is ambiguous and even controversial to some extent [38-41]. One possibility explaining the controversy is that metalloproteinases other than MMPs may contribute more to activating VSMC proliferation in vivo. In the current study, we demonstrated for the first time that ADAMTS-7 accelerated VSMC proliferation both in vitro and in vivo. However, the underlying mechanism is still elusive. Previously we have shown that ADAMTS-7 degrades matrix protein COMP in vessels [10]. COMP constrains VSMCs migration via maintaining VSMCs in a quiescent/contractile phenotype [11]. COMP itself interacts with BMP-2 and prevents VSMC transdifferentiation into an osteogenic phenotype [13]. Thus, ADAMTS-7 promotes neointima formation and vascular calcification via degradation of COMP $[10,12]$. It is thereby highly conceivable that ADAMTS-7 facilitates VSMCs replication through degradation of COMP. However, COMP manipulation by adenovirus does not affect VSMC proliferation in vitro. Hence it seems unlikely that ADAMTS-7 promotes VSMC proliferation via interfering with COMP. Further proteomics analysis is needed to identify a novel substrate of ADAMTS-7 and reveal the mechanism attributable to ADAMTS-7 mediated VSMC proliferation.

In summary, our studies illustrate pro-proliferative effects of ADAMTS-7 on VSMCs both in vitro and in an arterial injury model. These findings offer new insights into the role of ADAMTS-7 in VSMC biological behaviors. Inhibition of ADAMTS-7 not only retards VSMC migration, but also inhibits VSMC proliferation, which suggests ADAMTS-7 to be a potential therapeutic target for proliferative and migratory cardiovascular diseases such as atherosclerosis and restenosis.

The authors declare that they have no conflict of interest. All applicable institutional and/or national guidelines for the care and use of animals were followed.

We are grateful for the excellent technical assistance from the Peking University Health Science Center. This work was supported by funding from the International Cooperation and Exchanges of the National Natural Science Foundation of China (81220108004), the National Basic Research Program of China (2012CB518002), the National Natural Science Foundation of China (81070243, 81121061, 91339000), the National Science Fund for Distinguished Young Scholars (81225002), and Program of Introducing Talents of Discipline to Universities, Ministry of Education of China (B07001).

1 Lacolley P, Regnault V, Nicoletti A, Li Z, Michel JB. The vascular smooth muscle cell in arterial pathology: a cell that can take on multiple roles. Cardiovasc Res, 2012, 95: 194-204

2 Rudijanto A. The role of vascular smooth muscle cells on the pathogenesis of atherosclerosis. Acta Med Indones, 2007, 39: 86-93

3 Hao H, Gabbiani G, Bochaton-Piallat ML. Arterial smooth muscle cell heterogeneity: implications for atherosclerosis and restenosis 
development. Arterioscler Thromb Vasc Biol, 2003, 23: 1510-1520

4 Shi N, Chen SY. Mechanisms simultaneously regulate smooth muscle proliferation and differentiation. J Biomed Res, 2014, 28: 40-46

$5 \mathrm{Hu}$ J, Van den Steen PE, Sang QX, Opdenakker G. Matrix metalloproteinase inhibitors as therapy for inflammatory and vascular diseases. Nat Rev Drug Discov, 2007, 6: 480-498

6 Newby AC. Matrix metalloproteinases regulate migration, proliferation, and death of vascular smooth muscle cells by degrading matrix and non-matrix substrates. Cardiovasc Res, 2006, 69: 614-624

7 Sluijter JP, de Kleijn DP, Pasterkamp G. Vascular remodeling and protease inhibition - bench to bedside. Cardiovasc Res, 2006, 69: 595-603

8 Dwivedi A, Slater SC, George SJ. Mmp-9 and -12 cause n-cadherin shedding and thereby beta-catenin signalling and vascular smooth muscle cell proliferation. Cardiovasc Res, 2009, 81: 178-186

9 Liu CJ, Kong W, Ilalov K, Yu S, Xu K, Prazak L, Fajardo M, Sehgal B, Di Cesare PE. Adamts-7: a metalloproteinase that directly binds to and degrades cartilage oligomeric matrix protein. FASEB J, 2006, 20: 988-990

10 Wang L, Zheng J, Bai X, Liu B, Liu CJ, Xu Q, Zhu Y, Wang N, Kong W, Wang X. Adamts-7 mediates vascular smooth muscle cell migration and neointima formation in balloon-injured rat arteries. Circ Res, 2009, 104: 688--698

11 Wang L, Zheng J, Du Y, Huang Y, Li J, Liu B, Liu CJ, Zhu Y, Gao $\mathrm{Y}, \mathrm{Xu}$ Q, Kong W, Wang X. Cartilage oligomeric matrix protein maintains the contractile phenotype of vascular smooth muscle cells by interacting with alpha(7)beta(1) integrin. Circ Res, 106: 514-525

12 Du Y, Gao C, Liu Z, Wang L, Liu B, He F, Zhang T, Wang Y, Wang X, Xu M, Luo GZ, Zhu Y, Xu Q, Wang X, Kong W. Upregulation of a disintegrin and metalloproteinase with thrombospondin motifs-7 by mir-29 repression mediates vascular smooth muscle calcification. Arterioscler Thromb Vasc Biol, 2012, 32: 2580-2588

13 Du Y, Wang Y, Wang L, Liu B, Tian Q, Liu CJ, Zhang T, Xu Q, Zhu Y, Ake O, Qi Y, Tang C, Kong W, Wang X. Cartilage oligomeric matrix protein inhibits vascular smooth muscle calcification by interacting with bone morphogenetic protein-2 novelty and significance. Circ Res, 2011, 108: 917-928

14 Schunkert H, Konig IR, Kathiresan S, Reilly MP, Assimes TL, Holm H, Preuss M, Stewart AF, Barbalic M, Gieger C, Absher D, Aherrahrou Z, Allayee H, Altshuler D, Anand SS, Andersen K, Anderson JL, Ardissino D, Ball SG, Balmforth AJ, Barnes TA, Becker DM, Becker LC, Berger K, Bis JC, Boekholdt SM, Boerwinkle E, Braund PS, Brown MJ, Burnett MS, Buysschaert I, Cardiogenics, Carlquist JF, Chen L, Cichon S, Codd V, Davies RW, Dedoussis G, Dehghan A, Demissie S, Devaney JM, Diemert P, Do R, Doering A, Eifert S, Mokhtari NE, Ellis SG, Elosua R, Engert JC, Epstein SE, de Faire U, Fischer M, Folsom AR, Freyer J, Gigante B, Girelli D, Gretarsdottir S, Gudnason V, Gulcher JR, Halperin E, Hammond N, Hazen SL, Hofman A, Horne BD, Illig T, Iribarren C, Jones GT, Jukema JW, Kaiser MA, Kaplan LM, Kastelein JJ, Khaw KT, Knowles JW, Kolovou G, Kong A, Laaksonen R, Lambrechts D, Leander K, Lettre G, Li M, Lieb W, Loley C, Lotery AJ, Mannucci PM, Maouche S, Martinelli N, McKeown PP, Meisinger C, Meitinger T, Melander O, Merlini PA, Mooser V, Morgan T, Muhleisen TW, Muhlestein JB, Munzel T, Musunuru K, Nahrstaedt J, Nelson CP, Nothen MM, Olivieri O, Patel RS, Patterson CC, Peters A, Peyvandi F, Qu L, Quyyumi AA, Rader DJ, Rallidis LS, Rice C, Rosendaal FR, Rubin D, Salomaa V, Sampietro ML, Sandhu MS, Schadt E, Schafer A, Schillert A, Schreiber S, Schrezenmeir J, Schwartz SM, Siscovick DS, Sivananthan M, Sivapalaratnam S, Smith A, Smith TB, Snoep JD, Soranzo N, Spertus JA, Stark K, Stirrups K, Stoll M, Tang WH, Tennstedt S, Thorgeirsson G, Thorleifsson G, Tomaszewski M, Uitterlinden AG, van Rij AM, Voight BF, Wareham NJ, Wells GA, Wichmann HE, Wild PS, Willenborg C, Witteman JC, Wright BJ, Ye S, Zeller T, Ziegler A, Cambien F, Goodall AH, Cupples LA, Quertermous T, Marz W, Hengstenberg C, Blankenberg S, Ouwehand WH, Hall AS, Deloukas P, Thompson JR, Stefansson K, Roberts R, Thorsteinsdottir U, O'Donnell CJ, McPherson R, Erdmann
J, Consortium CA, Samani NJ. Large-scale association analysis identifies 13 new susceptibility loci for coronary artery disease. Nat Genet, 2011, 43: 333-338

15 Reilly MP, Li M, He J, Ferguson JF, Stylianou IM, Mehta NN, Burnett MS, Devaney JM, Knouff CW, Thompson JR, Horne BD, Stewart AF, Assimes TL, Wild PS, Allayee H, Nitschke PL, Patel RS, Consortium MIG, Consortium WTCC, Martinelli N, Girelli D, Quyyumi AA, Anderson JL, Erdmann J, Hall AS, Schunkert H, Quertermous T, Blankenberg S, Hazen SL, Roberts R, Kathiresan S, Samani NJ, Epstein SE, Rader DJ. Identification of adamts7 as a novel locus for coronary atherosclerosis and association of abo with myocardial infarction in the presence of coronary atherosclerosis: two genome-wide association studies. Lancet, 2011, 377: 383-392

16 Consortium CADCDG. A genome-wide association study in europeans and south asians identifies five new loci for coronary artery disease. Nat Genet, 2011, 43: 339-344

17 Pu X, Xiao Q, Kiechl S, Chan K, Ng FL, Gor S, Poston RN, Fang C, Patel A, Senver EC, Shaw-Hawkins S, Willeit J, Liu C, Zhu J, Tucker AT, Xu Q, Caulfield MJ, Ye S. Adamts7 cleavage and vascular smooth muscle cell migration is affected by a coronary-arterydisease-associated variant. Am J Hum Genet, 2013, 92: 366-374

18 Apte SS. A disintegrin-like and metalloprotease (reprolysin-type) with thrombospondin type 1 motif (adamts) superfamily: functions and mechanisms. J Biol Chem, 2009, 284: 31493-31497

19 Luque A, Carpizo DR, Iruela-Arispe ML. Adamts1/meth1 inhibits endothelial cell proliferation by direct binding and sequestration of vegf165. J Biol Chem, 2003, 278: 23656-23665

20 Rocks N, Paulissen G, Quesada-Calvo F, Munaut C, Gonzalez ML, Gueders M, Hacha J, Gilles C, Foidart JM, Noel A, Cataldo DD. Adamts-1 metalloproteinase promotes tumor development through the induction of a stromal reaction in vivo. Cancer Res, 2008, 68: 9541-9550

21 Stanton H, Rogerson FM, East CJ, Golub SB, Lawlor KE, Meeker CT, Little CB, Last K, Farmer PJ, Campbell IK, Fourie AM, Fosang AJ. Adamts5 is the major aggrecanase in mouse cartilage in vivo and in vitro. Nature, 2005, 434: 648-652

22 Glasson SS, Askew R, Sheppard B, Carito B, Blanchet T, Ma HL, Flannery CR, Peluso D, Kanki K, Yang Z, Majumdar MK, Morris EA. Deletion of active adamts5 prevents cartilage degradation in a murine model of osteoarthritis. Nature, 2005, 434: 644-648

23 Tortorella MD, Burn TC, Pratta MA, Abbaszade I, Hollis JM, Liu R, Rosenfeld SA, Copeland RA, Decicco CP, Wynn R, Rockwell A, Yang F, Duke JL, Solomon K, George H, Bruckner R, Nagase H, Itoh Y, Ellis DM, Ross H, Wiswall BH, Murphy K, Hillman MC, Jr., Hollis GF, Newton RC, Magolda RL, Trzaskos JM, Arner EC. Purification and cloning of aggrecanase-1: a member of the adamts family of proteins. Science, 1999, 284: 1664-1666

24 Furlan M, Robles R, Solenthaler M, Lammle B. Acquired deficiency of von willebrand factor-cleaving protease in a patient with thrombotic thrombocytopenic purpura. Blood, 1998, 91: 2839-2846

25 Salter RC, Ashlin TG, Kwan AP, Ramji DP. Adamts proteases: key roles in atherosclerosis? J Mol Med (Berl), 2010, 88: 1203-1211

26 Jonsson-Rylander AC, Nilsson $\mathrm{T}$, Fritsche-Danielson $\mathrm{R}$, Hammarstrom A, Behrendt M, Andersson JO, Lindgren K, Andersson AK, Wallbrandt P, Rosengren B, Brodin P, Thelin A, Westin A, Hurt-Camejo E, Lee-Sogaard $\mathrm{CH}$. Role of adamts-1 in atherosclerosis: Remodeling of carotid artery, immunohistochemistry, and proteolysis of versican. Arterioscler Thromb Vasc Biol, 2005, 25: 180-185

27 Sabatine MS, Ploughman L, Simonsen KL, Iakoubova OA, Kirchgessner TG, Ranade K, Tsuchihashi Z, Zerba KE, Long DU, Tong CH, Packard CJ, Pfeffer MA, Devlin JJ, Shepherd J, Campos H, Sacks FM, Braunwald E. Association between adamts1 matrix metalloproteinase gene variation, coronary heart disease, and benefit of statin therapy. Arterioscler Thromb Vasc Biol, 2008, 28: 562-567

28 Wagsater D, Bjork H, Zhu C, Bjorkegren J, Valen G, Hamsten A, Eriksson P. Adamts- 4 and -8 are inflammatory regulated enzymes expressed in macrophage-rich areas of human atherosclerotic plaques. Atherosclerosis, 2008, 196: 514-522 
29 Didangelos A, Mayr U, Monaco C, Mayr M. Novel role of adamts-5 protein in proteoglycan turnover and lipoprotein retention in atherosclerosis. J Biol Chem, 2012, 287: 19341-19345

30 Lindner V, Reidy MA. Proliferation of smooth muscle cells after vascular injury is inhibited by an antibody against basic fibroblast growth factor. Proc Natl Acad Sci USA, 1991, 88: 3739-3743

31 Ferns GA, Raines EW, Sprugel KH, Motani AS, Reidy MA, Ross R. Inhibition of neointimal smooth muscle accumulation after angioplasty by an antibody to PDGF. Science, 1991, 253: 1129-1132

32 Tsai S, Hollenbeck ST, Ryer EJ, Edlin R, Yamanouchi D, Kundi R, Wang C, Liu B, Kent KC. Tgf-beta through smad3 signaling stimulates vascular smooth muscle cell proliferation and neointimal formation. Am J Physiol Heart Circ Physiol, 2009, 297: H540-549

33 Min LJ, Mogi M, Li JM, Iwanami J, Iwai M, Horiuchi M. Aldosterone and angiotensin II synergistically induce mitogenic response in vascular smooth muscle cells. Circ Res, 2005, 97: 434-442

34 Grant MB, Wargovich TJ, Ellis EA, Caballero S, Mansour M, Pepine CJ. Localization of insulin-like growth factor I and inhibition of coronary smooth muscle cell growth by somatostatin analogues in human coronary smooth muscle cells. A potential treatment for restenosis? Circulation, 1994, 89: 1511-1517

35 Elledge SJ. Cell cycle checkpoints: preventing an identity crisis. Science, 1996, 274: 1664-1672

36 Koepp DM, Harper JW, Elledge SJ. How the cyclin became a cyclin: regulated proteolysis in the cell cycle. Cell, 1999, 97: 431-434

37 Vidal A, Koff A. Cell-cycle inhibitors: three families united by a common cause. Gene, 2000, 247: 1-15

38 Bendeck MP, Conte M, Zhang M, Nili N, Strauss BH, Farwell SM. Doxycycline modulates smooth muscle cell growth, migration, and matrix remodeling after arterial injury. Am J Pathol, 2002, 160: 1089-1095

39 Islam MM, Franco CD, Courtman DW, Bendeck MP. A nonantibiotic chemically modified tetracycline (CMT-3) inhibits intimal thickening. Am J Pathol, 2003, 163: 1557-1566

40 Cho A, Reidy MA. Matrix metalloproteinase-9 is necessary for the regulation of smooth muscle cell replication and migration after arterial injury. Circ Res, 2002, 91: 845-851

41 Galis ZS, Johnson C, Godin D, Magid R, Shipley JM, Senior RM, Ivan E. Targeted disruption of the matrix metalloproteinase- 9 gene impairs smooth muscle cell migration and geometrical arterial remodeling. Circ Res, 2002, 91: 852-859

Open Access This article is distributed under the terms of the Creative Commons Attribution License which permits any use, distribution, and reproduction in any medium, provided the original author(s) and source are credited. 